„Przekłady Literatur Słowiańskich”. T. 11, cz. 1, s. 1-27

ISSN 2353-9763 (wersja elektroniczna)

DOI https://doi.org/10.31261/PLS.2021.11.01.01

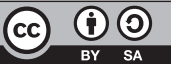

\title{
O literaturze bułgarskiej, języku i przekładzie Rozmowa z Wojciechem Gałązką
}

\section{On Bulgarian Literature, Language and Translation Interview with Wojciech Gałązka}

\author{
Wojciech Gałązka
}

\section{Sylwia Siedlecka}

iD https://orcid.org/0000-0002-6425-4654

UNIVERSITY OF WARSAW

s.siedlecka@uw.edu.pl

Data zgłoszenia: 2.10.2020 r. ～Data akceptacji: 26.01.2021 r.

ABSTRACT | The publication discusses the latest translation initiatives by Wojciech Gałązka, a Bulgarian and literary scholar and a translator of Bulgarian literature. Between 2019 and 2020, six works by Bulgarian writers and poets translated by Wojciech Gałązka were published: the novel Under the Yoke by Ivan Vazov (2020); volumes of verse Revealed from Anywhere by Petar Parvanov (2019), Seasons of Feelings by Petar Karaangov (2020), Moon Spots by Nikolay Liliev (2020), A Dream of Happiness by Pencho Slaveykov (2020), as well as poetic prose and poems included in the collection Against the Absence by Nikolay Kantchev (2020). The review has been supplemented with a commentary on specific problems related to translation practice, such as sound and grammatical structures, the translatability of idiomatic expressions, taking into account the literary convention in translation and issues related to the understanding of translation as an intercultural transfer.

KEYWORDS | Wojciech Gałązka, Bulgarian literature, Polish literature, Bulgarian language, translation, cultural transfer 
Wojciech Gałązka (1947) — polski bułgarysta, literaturoznawca, wybitny tłumacz na język polski wielu utworów należących do kanonu literatury bułgarskiej, dyplomata. Studiował filologię słowiańską na Uniwersytecie Jagiellońskim, po ukończeniu studiów wykładał w Katedrze Filologii Bułgarskiej UJ. W latach 1992-1993 był lektorem języka polskiego na Uniwersytecie Sofijskim. W 1993 roku rozpoczął pracę w Ministerstwie Spraw Zagranicznych RP, a w latach 1993-1999 pełnił funkcję dyrektora Instytutu Polskiego w Sofii. W latach 2003-2007 konsul generalny RP w Łucku (Ukraina), a w latach 20082012 konsul RP w Sofii. Laureat między innymi odznaczeń „1300 lat Bułgarii”, Orderu „Jeździec z Madary”, a także Nagrody im. Eutymiusza Tyrnowskiego przyznawanej przez Uniwersytet w Wielkim Tyrnowie. Doktor honoris causa Uniwersytetów w Wielkim Tyrnowie i w Łucku. Autor książek: Tradycja i współczesność. O literaturze bułgarskiej XX wieku (1983), Bułgarskie programy i manifesty literackie (1983), Naród i kultura. Antologia esejów i artykułów o narodzie i kulturze bułgarskiej (1985), Oswajanie skorpionów (1993). Wśród jego przekładów bułgarskiej literatury są między innymi: Geo Milewa Poematy i proza liryczna (1977), Georgiego Karasławowa Tango (1977), Emiliana Stanewa Antychryst (1979), Georgiego Rajczewa Lustig i inne opowiadania (1980), Atanasa Dałczewa Proza poetycka (1981), Nikołaja Kynczewa Niczym ziarno gorczycy (1981) oraz Posłanie od piechura (1999), Zdrawka Kisiowa Czystopis (2007), Petyra Pyrwanowa Skadkolwiek wyjawiony (2019), Petyra Karaangowa Sezony uczuć (2020), Nikołaja Liliewa Odblaski księżyca (2020), Pencza Sławejkowa Sen o szczęściu (2020), a także nowy przekład powieści Iwana Wazowa Pod jarzmem (2020).

W wywiadzie dla bułgarskiego portalu „Kultura”, mówiąc o pracy nad przekładem Pod jarzmem Iwana Wazowa, określił Pan swoją rolę jako uważnego czytelnika i pośrednika między autorem a kulturą rodzimą. Jak Pan tę rolę rozumie?

Tłumacze różnie definiują swoją rolę. Słyszałem, że jeden przyrównał się do listonosza. Rozumiem intencję, ale porównanie to jest trochę niezręczne, bo listonosz przecież nawet nie czyta doręczanych listów, a wręcz nie powinien. Ja mam na swój użytek formułę uważnego czytelnika jako pierwszego niezbędnego warunku do spełniania roli tłumacza literatury pięknej. Uważny czytelnik to taki, który powinien starać się rozumieć literaturę i mieć świadomość reguł i zasad, jakimi się rządzi, by móc je dostrzec i zinterpretować w danym utworze przed przystąpieniem do przekładu. Drugi warunek niezbędny to świadomość, że tłumaczenie, przekład - w obu przypadkach nomen omen - są przeniesieniem jednego języka w drugi i jednej kultury w drugą. I tu tłumacz jest w roli 
pośrednika. Oczywiście powinien mieć też świadomość, że więcej w jego pracy ograniczeń niż swobody, a zwłaszcza swobody graniczącej z dowolnością. Pocieszające jest to, że ograniczenia tego samego rodzaju ma prozaik lub poeta, kiedy siada do pisania i tworzy. Zresztą występuje Pani także w roli pisarki, więc odczuwa to Pani na własnej skórze, ujmując rzecz... metaforycznie.

Wśród nowych przekładów lub wznowień przekładów literatury bułgarskiej, których jest Pan autorem, najwięcej jest poezji. Na ile wynika to $\mathrm{z}$ Pana zainteresowania poezją jako taką, a na ile $\mathrm{z}$ faktu, że poezję bułgarską uważa Pan za fenomen szczególnego rodzaju?

W swojej długo już trwającej działalności popularyzatorskiej, jako badacz literatury bułgarskiej i tłumacz, rzeczywiście dużo uwagi poświęcam poezji. O tendencjach rozwojowych poezji bułgarskiej w okresie międzywojennym była moja praca doktorska, a wcześniej, jeszcze na studiach, pisałem o poezji Atanasa Dałczewa i Nikołaja Liliewa. Jako student drukowałem w czasopismach sporo przekładów współczesnych młodych poetów bułgarskich. Lubię poezję, ale to nie znaczy, że lubię ją bardziej niż prozę. I nie znaczy też, że poezję bułgarską uważam za fenomen szczególnego rodzaju, może z wyjątkiem pieśni ludowych. Wiele się nimi nie zajmowałem, choć w ostatnich latach postawiłem sobie ambitny cel, aby przetłumaczyć przygotowany przez Pencza Sławejkowa zbiór pieśni ludowych Ksiegga pieśni (Книга на песните), który wydał w 1917 roku, już po jego śmierci, wielki literacki przyjaciel Sławejkowa, dr Krystiu Krystew. Ten bardzo obszerny zbiór rzeczywiście jest swoistym fenomenem, ale można to pokazać $\mathrm{w}$ dość dużym wyborze zamieszczonych tam pieśni. Wyznaczone zadanie udało mi się zrealizować jedynie w niewielkiej części.

Jednym słowem, interesuje mnie poezja w ogóle i chyba jestem od długiego już czasu jedynym bułgarystą, który tłumaczy poezję. Po śmierci krakowskiego poety Jana Zycha, znającego bułgarski, po śmierci poetki Anny Kamieńskiej i zaniechaniu tłumaczeń przez duet Jacka i Dimitriny Bukowskich nikt inny nie przyłączył się do naszego niewielkiego grona. Ogromną większość przekładów w antologiach, w tym w mojej antologii Niewidzialne skrzydła, robili poeci polscy z tzw. rybki. Te przekłady pozostawiają wiele do życzenia. W przypadku poezji Pencza Sławejkowa i Nikołaja Liliewa zrobiłem te przekłady od nowa. 
Można zawrzeć Pana zainteresowania translatorskie w ogólniejszej formule?

Pociągają mnie utwory wyraziste w swojej stylistyce i w przekazie. I nie ma znaczenia, czy są to utwory poetyckie czy proza. Ale zrobiłem też wiele przekładów, które były gestem przyjaźni literackich, bo i w ten sposób pojmuję swoją rolę. Dobrze, jeśli te gesty przyjaźni współgrały z wyżej wskazanymi kryteriami. A na ogół tak właśnie było i jest. Oczywiście były też przekłady wynikające $z$ bułgarystycznej potrzeby. I nawet nieco z powodu sentymentu do pewnego fragmentu utworu. Tak przetłumaczyłem poemat Wazowa Опвлченичите на Шипка z tomu Ерореја zapomnianych, ponieważ zawsze podobała mi się tylko jego pointa, wypowiedziana jakby jednym tchem:

днес йощ Балканът, щом буря зафаща,

спомня тоз ден бурен, шуми и препраща

славата му дивна като някой ек

от урва на урва и от век на век!

W eseju o nieliterackości literatury bułgarskiej ze zbioru Oswajanie skorpionów z 1992 roku pisał Pan, że literatura bułgarska szuka inspiracji w autentyzmie życia oraz że powieść jest gatunkiem obsługującym „wielkie” tematy, dystansującym się od potoku zwykłego życia, zaś bliżej tych „mniejszych”, choć wcale nie mniej ważnych, tematów są mniejsze formy, jak opowiadanie. A czy kryterium (nie)literackości można, Pana zdaniem, odnieść również do bułgarskiej poezji?

Ta dychotomia literackości i nieliterackości - nieliterackości rozumianej bynajmniej nie negatywnie - którą można by nazywać też dychotomią konwencjonalności i niekonwencjonalności, jest w pewnym sensie kołem napędowym literatury bułgarskiej. Przynajmniej w pewnych jej okresach epoki nowożytnej. Dość pamiętać, że u początków nowej literatury bułgarskiej są dwa utwory niemające statusu literackości także wtedy, kiedy powstawały: Historia słowianobułgarska (1762) Paisija Chilendarskiego i Cierpienia grzesznego Sofroniusza (przed 1813) Sofroniusza Wraczanskiego. Pierwszy jest opowieścią o historii, drugi autobiografią. Nim zostaną opublikowane w drugiej połowie XIX wieku, są w obiegu w formie rękopisów. Nie mieszczą się one w żadnych regułach XIX-wiecznej literackości, zwłaszcza w kategorii gatunku literackiego, ale mają walory literackie. Tłumaczenie Cierpień... dało mi zresztą sporo satysfakcji literackiej. Później Wazow powieścią Pod jarzmem sięga po gatunek powieści przygodowej, ale narusza jego konwencjonalność — i do- 
brze, że to czyni - licznymi dygresjami publicystycznymi i eseistycznymi. Potem nadchodzi znaczna fala imponującej memuarystyki, o dużych walorach literackich (Zachari Stojanow, Stojan Zaimow, Simeon Radew i inni). Funkcjonalnie, jak twierdził ex post prof. Tonczo Żeczew, spełnia ona zastępczo rolę wielkiej powieści realistycznej, typowej dla XIX wieku. Ta memuarystyka ma oczywiście również duże walory literackie i dotyczy ważnych, przełomowych momentów w nowożytnej historii Bułgarii.

$\mathrm{W}$ okresie modernizmu, a zwłaszcza nurtu symbolistycznego w nim, dochodzi do radykalnego skonwencjonalizowania literatury i literackość jest jednym z jej głównych wyróżników. Do tego stopnia, że symbolista Nikołaj Liliew doprowadza tę konwencjonalność do takiej perfekcji, że zamyka już sobie dalszą perspektywę rozwojową i w latach 30 . XX wieku rezygnuje z pisania. Niemal równolegle z nim Atanas Dałczew przeciwstawia się symbolistycznej poetyckości motywami, metaforami i wersyfikacją, które odbierane są w kontekście symbolizmu jako niepoetyckie, czy poetyckie inaczej („над старото тържище ален бе залезът като домат”), a Nikoła Wapcarow w latach 30. pisze „не, сега не е за поезия” oraz „и стихове пиша тъй както умея”, tworząc poezję wysokich lotów z materiału literackiego, który wcześniej nigdy nie otrzymałby kwalifikacji jako godny poezji. W tym samym czasie pojawia się cała rzesza prozaików i poetów, których ja gdzieś nazwałem autentystami i którzy nie są wybitni, ale stanowią nowe zjawisko literackie, do dziś szczegółowo niezbadane. Polega ono najogólniej na tym, że status ja lirycznego czy narratora jest tożsamy ze statusem i doświadczeniami życiowymi twórcy. Poza tym pojawiają się takie formy wypowiedzi jak list, reportaż, opowieść autobiograficzna itp. Można tych twórców Polakowi przybliżyć, wskazując choćby na Zaklęte rewiry Henryka Worcella. Dość wymienić tu prozę Borisa Sziwaczewa lub Matweja Wylewa, w poezji Mariję Grubeszliewą. Ale jest ich wielu. Tę problematykę można by śledzić także w późniejszym czasie.

W 2020 roku ukazał się w Wydawnictwie Miniatura tom poezji Petyra Karaangowa Sezony uczuć. Co Pana skłoniło do tego, żeby spolszczyć wiersze tego autora?

Petyra Karaangowa przetłumaczyłem pod koniec lat 80. Akurat wtedy, kiedy wydanie tomiku przekładów przestało już być sprawą oczywistą. Wolny rynek zaczynał rządzić rynkiem księgarskim, a poza tym komu wówczas była w głowie poezja - mnie też nie była. Do tego stopnia, że robiąc kilka lat temu porządki w szpargałach, ze zdumieniem odkryłem, że mam tomik Karaangowa w swoim archiwum. Przeczytałem i stwierdziłem, 
że się nie zestarzał. To poeta z tzw. pokolenia kwietniowego, które debiutowało po 1956 roku, w okresie odwilży politycznej, i wniosło pewne ożywienie do poezji bułgarskiej, a przede wszystkim sporą dozę liryzmu, świeżość języka poetyckiego i środków wyrazu, co po latach obowiązywania rygorystycznej doktryny realizmu socjalistycznego robiło wrażenie, a nawet doprowadziło do pewnej mitologizacji tego pokolenia. Nieuzasadnionej, jak każda mitologizacja. Karaangow funkcjonował na obrzeżach tego pokolenia. Był poetą wyciszonym, wyrażającym stany uczuć, zresztą nie tylko osobistych, w kameralnym rejestrze klimatów pór roku. Ta koncepcja bardzo mi odpowiadała, była gwarantem i emanacją szczerości wypowiedzi. Tomik Sezony uczuć jest wyborem z całej twórczości Karaangowa, której zaniechał po wydaniu w 1984 zbioru Зимни недели (Zimowe niedziele). Warto też zaznaczyć, że tłumaczył poezję polską w antologii Съвременни полски поети (Współcześni poeci polscy), wydanej w 1967 roku, która odegrała ważną rolę w ówczesnych przemianach poezji bułgarskiej. Zainteresowanie naszą poezją zrodziło się w czasie jego kilkuletniego pobytu w Polsce. Ma w swoim dorobku kilka wierszy pisanych Gałczyńskim, do którego zbliża go też liryczna emanacja uczuć.

W 2019 roku został wydany Pański przekład utworów Petyra Pyrwanowa Skądkolwiek wyjawiony. To obszerny wybór z twórczości tego autora, którego bardzo Pan ceni.

Z Petyrem Pyrwanowem łączy mnie ponad pięćdziesięcioletnia przyjaźń, nie tylko literacka. Zacząłem go tłumaczyć i publikować już jako student: w „Studencie”, w krakowskim „Magazynie Kulturalnym”, chyba także w „Życiu Literackim”. Jednak dopiero kilkanaście lat temu zająłem się tym z większą konsekwencją. Tom Skądkolwiek wyjawiony jest rzeczywiście wyborem z całej jego twórczości, której obszerny wybór przyniósł już w 2016 roku zbiór Отвъд хоризонта на битието (Poza horyzontem bytu). Ale moje przekłady zamieszczonych tam wierszy powstawały wcześniej i dość długo dojrzewały. To dla tłumacza bardzo trudny poeta. Dlatego właśnie zdecydowałem się na wydanie dwujęzyczne jego utworów. Trudny w pierwszej kolejności dlatego, że prawie w ogóle nie używa interpunkcji, co w wypadku języka bułgarskiego, pozbawionego deklinacji, bardzo komplikuje śledzenie związków logicznych. Sprawia też często, że wiele z nich powstaje jakby „na biegu wstecznym”, czego po polsku właściwie nie da się zastosować, choć tu i ówdzie próbowałem. 


\section{Na czym ten „wsteczny bieg” polega?}

Już spróbuję wyjaśnić. Najlepiej to zrobić na przykładzie. Weźmy choćby dwa ostatnie wersy wiersza herbata przelewa się z filiżanki..., który jest na stronie 82. Można je czytać tak, jak ja je przeczytałem w przekładzie, „stosując” potencjalną interpunkcję, czyli na „biegu wstecznym”:

обратът към съдбата е отворил яснота в прозореца

саждив и окислен, дъждът дълбок се рони неизбежно

a można też czytać inaczej:

обратът към съдбата е отворил яснота в прозореца,

саждив и окислен, дъждът дълбок се рони неизбежно

i wówczas epitety „саждив и окислен” można by odnieść albo do okna, albo do deszczu, ale tylko po bułgarsku. W przekładzie tego efektu już by nie było i fragment ten brzmiałby jak „ciemny (osmolony?) i kwaśny, ulewny deszcz [...]”. Nie brzmi to teraz zręcznie, ale deszcz można by nazwać w wierszu mianem „саждив”, skoro i grzyba, zwanego po polsku gąską niekształtną, nazywa się „саждива гъба”.

Istnieje też trzecia możliwość, jeśli nadal chce się projektować interpunkcję oraz „wsteczny bieg” w czytaniu, i wtedy „саждив и окислен” odnosiłyby się tylko do deszczu, a w przekładzie ten fragment musiałby brzmieć jak wyżej, czyli epitety byłyby w mianowniku:

обратът към съдбата е отворил яснота в прозореца, саждив и окислен - дъждът дълбок се рони неизбежно.

Tłumacz musi tu o wszystkim rozstrzygać sam, nie mając skutecznego oparcia w gramatyce. A przetłumaczyć na nasz język wiersza możliwego do przeczytania i na „pierwszym biegu”, i na „wstecznym biegu” chyba się nie da.

\section{Pyrwanow jest też poetą erudycyjnym.}

Jego poezja jest zatopiona w wielu kulturach klasycznych: w greckim antyku, w kulturze hebrajskiej, chińskiej, z których Pyrwanow wywodzi również formę i styl wypowiedzi. Można by rzec, że poszukuje w nich poetyckiej mądrości, syntezy myśli w poetyckim obrazie. Dlatego mamy u niego również pewien rodzaj emocjonalnego wyciszenia, czy też emocji, których źródłem jest myśl. Krytyk Swetłozar Igow opatrzył jego poezję mianem postklasycznej - trafnym w odniesieniu do jej formuły konceptualnej. Jednocześnie poeta wychodzi zawsze „poza horyzont bytu”, sam akt kreacji nie ma zakotwiczenia w tu i teraz. To zakotwiczenie jest w kulturze 
i w przestrzeniach nierzeczywistych, czytaj — nieziemskich. Nawet ogród jest „ogrodem na dachu”, że odwołam się do tytułu jednego z cykli wierszy.

Twórczość Karaangowa i Pyrwanowa łączy co najmniej kilka nici. Dramaturgia tych utworów jest ukryta, jest w nich spokój, nawet kontemplacja, a jednocześnie dynamika, ruch, ciągła przemiana, która wcale tej kontemplacji nie wyklucza, a - jak mi się zdaje - jest właśnie dzięki niej możliwa. W poezji Pyrwanowa zwłaszcza, którą widzę w ciągłej zmianie stanów skupienia, w momencie przeistaczania się, bez przyszpilania sensów.

Bardzo mnie cieszy to Pani spostrzeżenie. Ja też sądzę, że tak właśnie jest, że dramaturgia jest u nich dalece stonowana, ale są tu stany napięcia podpowierzchniowe. I to one decydują zawsze o przekazie poetyckim, powiedziałbym nawet, że przynoszą nie tylko obraz, ale i wzruszenie. Literatura to taka „piękna nierzeczywistość”, jak mówi Olga Tokarczuk, literatura to niedopowiedziany, zastępczy opis świata. Bardzo się cieszę, że wspólnie z Petyrem Pyrwanowem udało nam się przygotować tomiki poezji Leśmiana i Norwida. Niby poetów różnych od jego poezji, ale zarazem bliskich.

Rytmizacja, brzmienie są ważnymi elementami w Pana przekładach bułgarskiej poezji. Jak Pan widzi pracę w językach, które mimo że należą do rodziny słowiańskiej, różnią się jednak znacząco pod względem brzmienia słów, rytmu, melodii? Czy muzyczna świadomość jest dla Pana ważnym punktem odniesienia w pracy przekładowej?

Nie ma chyba wśród znanych mi języków żadnego, który byłby brzmieniowo tożsamy z innym, a tym bardziej z innymi. Jeśli nawet ich brzmienie jakoś je zbliża, to przecież zestaw samogłosek, a zwłaszcza spółgłosek, zazwyczaj inaczej rozkłada się w poszczególnych jednostkach leksykalnych, a te, jako nośniki znaczeń, nie mogą być przyporządkowywane do utworu głównie pod kątem brzmienia, jakie ze sobą wnoszą. W poezji klasycznej, czyli takiej, w której obowiązują ścisłe, lub w miarę ścisłe, zasady wersyfikacyjne i strofika, brzmienie utworu jest w znacznym stopniu regulowane przez te zasady i niektóre inne zabiegi, jak choćby paralelizm. W poezji tworzonej poza rygorem wersyfikacyjnym wygląda to inaczej, co nie oznacza, że nie ma w niej rytmu, choćby składniowego, i orkiestracji brzmieniowej, czyli takiego doboru jednostek leksykalno-znaczeniowych, w których zbiegają się z dużą częstotliwością zbliżone dźwięki samogłoskowe i spółgłoskowe. Tłumacz musi to sobie każdorazowo rozstrzygać, być na tyle uważnym czytelnikiem, aby móc to wszystko dostrzec i zinterpretować. Oczywiście do tego potrzebna jest 
pewna konkretna wiedza o poezji, ale nie wyspecjalizowana wiedza muzyczna, choć poezja była kiedyś nazywana pieśnią. Ze względu na różnice foniczne między językami, w gruncie rzeczy nieprzezwyciężalne, tłumacz nie tyle powinien szukać zbliżenia brzmieniowego, ile stwierdzić, że w danym utworze brzmieniowość odgrywa istotną rolę, określić stopień jej nasycenia i użyte środki jej uzyskania. To jest cel najważniejszy, pożądany i maksymalistyczny. Mogą temu towarzyszyć poniekąd zabawne konstatacje, sugerujące na przykład, że „motyl” w języku polskim i „пеперуда” w języku bułgarskim, aczkolwiek w pełni tożsame znaczeniowo, wywołują $\mathrm{w}$ odbiorze na tyle odmienne asocjacje brzmieniowe, że w utworze poetyckim może to rzutować na różną aurę „dźwięczności” ich lotu. To nie znaczy, rzecz jasna, że któraś z nich jest bardziej lub mniej pasująca do motyli, ona jest po prostu inna. Podam taki przykład, zestawiając strofę wiersza Nikołaja Liliewa w oryginale z moim przekładem:

Светло утро, ти прокуди

Всяка пара и мъгла -

Пеперуди, пеперуди

Тънки сребърни крила.
Jasny ranku, trwałeś chwilę, by mgły wznieść powiewem i motyle, i motyle, srebrnych skrzydeł zewem.

Można odnieść wrażenie, że istotą motyla w języku bułgarskim są kruchość i delikatność, a w polskim - lekkość i zwiewność (zwłaszcza że zastosowałem inny rodzaj rymów i stóp rytmicznych w wersie drugim i czwartym). Cechą wspólną w tej istotności jest nietrwałość jego bytu. Zgodna zresztą z prawdą obiektywną. Sam lot motyla podczas jasnego i (jak można się domyślić) rześkiego poranka, tuż po akcie kreacji świata z mgieł, sugerowany jest występującymi naprzemiennie różnymi stopami rytmicznymi.

Przenosząc różne doświadczenia teoretyczne na prostą pragmatykę przekładu, wiem z doświadczenia, że bardzo przydaje się głośne czytanie tekstu, czy to wiersza, czy prozy. To trochę tak jak w jazzie: pojawia się na początku jakiś motyw muzyczny i potem pamięć muzyczna może go przywoływać wielokrotnie i robić $\mathrm{z}$ nim także różne wariacje.

Muzyka w przekładzie nie tyle jest dla mnie układem odniesienia, ile materiałem odtwórczym. Mówiąc ostrożniej, zaledwie próbuję ją odtwarzać, a jeszcze bardziej ostrożnie - uwydatnić jej obecność, bo przecież nie dysponuję tymi samymi narzędziami muzycznymi, co muzyk; barwy dźwięków w innym języku są trudne do odwzorowania i w ogóle materiał twórczy jest inny. Wyobrażam sobie, jak trudne jest to na przykład dla tłumacza poezji koreańskiej, kiedy pomyślę, że w języku koreańskim używane są nagminnie ideofony. To dla mnie pocieszające. 
Jest Pan autorem przekładu wyboru z twórczości Pencza Sławejkowa, wybitnego poety modernisty, który inspirował się bułgarską pieśnią ludową. Ta rola twórczości ludowej jest w ogóle znacząca dla bułgarskiej literatury. Na czym ten transfer ludowości do literatury, a zwłaszcza poezji, polegał?

Jeśli myślimy o bułgarskich pieśniach ludowych w sensie wykonawczym, to chciałbym wskazać na dwie charakterystyczne okoliczności, odróżniające je od naszych polskich wyobrażeń. Po pierwsze ich wykonywanie ma charakter rytualny, nie odbywa się poza określonym rytuałem kulturowym. Po drugie, ich zaśpiewanie wymaga wielkiego głosu i śpiewaka. Polskie pieśni ludowe są najczęściej śpiewane jako piosenki biesiadne, szczególnie te weselne, jako przyśpiewki. Można je też spokojnie śpiewać zbiorowo. Bułgarskich zbiorowo zaśpiewać się nie da, ponieważ są one wykonawczo bardzo trudne. Można je śpiewać wielogłosowo, co jest jeszcze trudniejsze, gdyż głosy się na siebie nakładają lub na siebie zachodzą. Miałem okazję być wiele, wiele lat temu na kliku weselach w Bułgarii i na żadnym nie były śpiewane ani indywidualnie, ani zbiorowo pieśni weselne. O ojcu mojego starego przyjaciela z regionu Strandży, pracującym całe życie w kamieniołomie, okoliczni powiadali, że był jednym z najwspanialszych śpiewaków. Ale on zaśpiewał w życiu zaledwie parę razy, pewnie podczas lokalnych świąt, obchodzonych zbiorowo. Ktoś zapyta: a dlaczego tylko parę razy, skoro był tak dobrym śpiewakiem? Odpowiedź jest jedna: bo tylko wtedy wewnętrznie, duchowo utożsamiał się z treścią takiej pieśni, a utożsamiał się ze względu na szczególne doznania własne w określonym momencie życia, których presja rodziła potrzebę wyrażenia ich śpiewem. Jego niepowtarzalny stan duchowy, wewnętrzne napięcia szukały ujścia i wyrazu. To decydowało również o jakości i dramatyzmie wykonania. To mam także na myśli, mówiąc o rytualności, nie tylko moment obrzędowy. Nam to trudno przychodzi zrozumieć.

Jeśli natomiast myślimy o pieśni ludowej jako o inspiracji dla poezji, to skala tego zjawiska jest nieporównywalnie większa niż w poezji polskiej. Obejmuje ono poetów odrodzenia narodowego w połowie XIX wieku, a ponadto bardzo wielu wybitnych poetów późniejszych, poczynając od Christa Botewa, Iwana Wazowa, Pencza Sławejkowa, Peja Jaworowa, Kiriła Christowa, Asena Razcwetnikowa, Elizawety Bagriany, a nawet Nikoły Wapcarowa, a kończąc na najbliższym współczesności Płamenie Dojnowie. Inspiracje te szczególnie zauważalne i ważne są w pierwszej fazie moderny. Sprowadzają się do różnego rodzaju stylizacji, ale i do swoistego oglądu, w którym podmioty świata przedstawionego są wpisywane w mit, a składniki przedmiotowe w rezultacie personifikacji odgry- 
wają role społeczne. Tradycja pieśni ludowej uobecnia się w poezji także niezliczoną ilością mott, za którymi nie idzie stylizacja. Są one swoistą „intonacją" w warstwie metaforycznej poszczególnych utworów. Chyba największą karierę, bo i w prozie, zrobily pieśni ludowe mające incipium „Oj, lesie, lesie zielony.... Ten zielony las obsługuje wiele metafor, ale mam wrażenie, że przede wszystkim jest oparciem dla marzenia, tęsknoty, żalu $\mathrm{z}$ powodu przemijania.

W jakim stopniu świadomość pieśni ludowej była dla Pana ważna w procesie przekładu Snu o szczęściu i wyboru z Księgi pieśni Sławejkowa? Jak zazębiała się ona $\mathrm{z}$ autorskimi wizjami Sławejkowa? Jak dalece ten autor ingerował w pieśń ludową i co z niej szczególnie chętnie wydobywat?

Nie cała twórczość Sławejkowa jest związana z pieśnią ludową. Tom liryków Sen o szczęściu, do którego nawiązuje obszernym wyborem wierszy mój tomik przekładów z tym właśnie tytułem, to czysta liryka wyznaniowa, w której modernistyczny ideał nieosiągalnej harmonii łączy się z nastrojowością i ulotnością marzenia. To poezja bez żadnych zobowiązań, a jedynie emanacja poetyckiego „ja” twórcy. Mówi się, że literacki druh Sławejkowa, poeta Pejo Jaworow, rzucił ten tomik z wieży Eiffla w symbolicznym geście literackiej jedności poezji bułgarskiej z europejską. Proszę zwrócić uwagę, że nie tylko w wyborze przekładowym, ale i w oryginalnym tomie Snu o szczęściu nie ma ani jednego wiersza, który miałby tytuł. To tytuł samego tomu ukierunkowuje odbiór, w nim jest pełne przesłanie. Podobnie mamy u Liliewa w zbiorze Odblaski księżyca.

Jednocześnie pieśń ludowa, a zwłaszcza miłosne pieśni ludowe, były dla Sławejkowa programowo ważne, czemu dał wyraz także w obszernym studium im poświęconym. Dochodzi w nim do wniosku - czyniąc również porównania $\mathrm{z}$ francuską, włoską i serbską - że bułgarska miłosna pieśń ludowa, niezależnie od tonów melancholijnych, jakże nieuniknionych, wyróżnia się na tym tle radością życia i podniosłością. Nie ma w niej nieprzyzwoitych zaczepek i motywu zdrady. Sławejkow, zgodnie ze swoją koncepcją wstydliwego realizmu, chciałby jedynie taką miłość widzieć. Jako nieskończone zespolenie dwóch dusz. W rzeczywistości tak nie jest, czego dowodzą współcześnie choćby prace Fłorentiny Badałanowej. Ale to temat na elaborat, natomiast wracając do poetyckich związków Sławejkowa z pieśnią ludową, to chciałbym wskazać na tom Pieśni epickie, w którym jest sporo utworów balladowych. Część z nich uwzględniłem w swoim wyborze: Szaławiła, Nierozłączni, Smocza ukochana, Pora tajemną. Do Nierozłącznych mam sentyment, bo śpiewałem ten utwór 
setki razy. W przekładzie też można go zaśpiewać na melodię bułgarską. Nawiązują one do motywów ludowych, ale i do pewnych środków wyrazu. Kluczową rolę odgrywa jednak przygotowany przez Sławejkowa zbiór pieśni ludowych Księga pieśni. Zarówno charakter zamieszczonych w nim utworów, jak i kompozycja samego zbioru sprawiają, że wbrew pozorom jest to dzieło autorskie. Decyduje o tym fakt, że Sławejkow wyjmuje $\mathrm{z}$ tekstów oryginalnych pewne ich fragmenty, tworzy strofy, wprowadza tu i ówdzie rymy. Jednym słowem, tworzy bardzo często nowe utwory. Cały układ kompozycyjny zaś, zorganizowany tematycznie, kreuje wizję świata w pieśni ludowej, której świat jest jakby upostaciowioną na kształt ludzki całością. Ma ludzką duszę. W moim wyborze utwory z Księgi pieśni jedynie to sygnalizują, gdyż całość, ze względu na dużą objętość, wymaga odrębnej publikacji.

Tłumaczył Pan Sławejkowa, który przecierał szlaki poezji modernistycznej, ale tłumaczył Pan też autorów schyłku modernizmu. Czy ta perspektywa usytuowania danego twórcy w pewnym ciągu narodzin i dojrzewania form jest jakiegoś rodzaju „tematem”, kwestią istotną w twórczości przekładowej?

Akurat tak się szczęśliwie złożyło, że prezentuję poetę z pierwszej fazy moderny bułgarskiej i poetę zamykającego tę formację literacką. Jednakże nie to było moim celem. Chciałem przede wszystkim pokazać dwóch dobrych poetów. Oczywiście w jakimś reprezentatywnym wyborze. O każdym z nich można by powiedzieć, że jest szczytem wrażliwości poetyckiej, ale jest ona nieco odmienna ze względu zarówno na odmienne rysy indywidualne, jak i na wyjściowe podstawy programowe i estetyczne. Mimo wszystko szukałem w samym wyborze pewnych podobieństw między nimi. Nic nie jest aż tak doskonałe, żeby powiedzieć, iż wszystko się udało. Chciałem na przykład pokazać, że łączy ich temat miasta. Przetłumaczyłem Koszmar Sławejkowa, ale Liliew ma poemat Градъm (Miasto), którego nie udało mi się przetłumaczyć, a z punktu widzenia reprezentatywności byłby cenny. „Vita brevis, ars longa”...

Jest Pan tłumaczem literatury pięknej i autorem prac naukowych. Jak te dwie ścieżki mają się do siebie w Pana przypadku? Czy z którymś $\mathrm{z}$ tych obszarów bardziej się Pan identyfikuje?

Identyfikuję się z każdym z tych obszarów, ale od dość długiego czasu praktykuję już tylko działalność w pierwszym z nich. Zdarza mi się jeszcze napisać od czasu do czasu jakiś artykuł, ale trudno to nazwać działalnością naukową. Robiąc sobie prawie dwudziestoletnią przerwę 
w aktywności naukowej, nie byłem już w stanie nadrobić ogromnych zaległości, a i oczy mi tego nie ułatwiają. Bardzo ceniłem sobie także pracę ze studentami, która jest niesłychanie inspirująca naukowo, bo każde, nawet najbardziej naiwne, pytanie wymaga w odpowiedzi posłużenia się konkretem jako argumentem perswazyjnym i interpretacyjnym.

Czy na zajęciach ze studentami miał Pan taki wstępny, progowy tekst, za pomocą którego uchylał Pan studentom drzwiczki do bułgarskiej literatury? Nawet jeśli takiego nie było, jaki to mógłby być utwór hipotetycznie? Lub jeszcze inaczej: jaki tekst zaproponowałby Pan polskiemu czytelnikowi, który nie zna bułgarskiej literatury ani kultury, a chciałby ją bliżej poznać (nie wątpię zresztą, że o taką radę pytano Pana nie raz i nie dwa)?

Nie pytano mnie. Zawsze miałem wrażenie, że w naszym polskim środowisku bułgarystycznym zadajemy sobie nawzajem mało pytań. Nigdy nie było to środowisko liczne. Każdy z nas pielęgnował swoje poletko i komunikacja między nami była ograniczona, choćby dlatego, że te poletka były od siebie dość odległe. Muszę powiedzieć, że więcej dawało mi komunikowanie się z kolegami z innych kierunków, którzy byli pod ręką: Jackiem Baluchem, Marią Dąbrowską-Partyką, Julianem Kornhauserem. Bułgarystycznie czułem się dość samotnie. Pamiętam, że przy okazji jakichś spotkań konferencyjnych, referatów prof. Teresa Dąbek-Wirgowa, którą ceniłem zwłaszcza za jej Historię literatury bułgarskiej, mawiała do mnie w charakterze komentarza: „Panie Wojtku, ale umówmy się, że to nie tak", ale nigdy nie było ciągu dalszego - co i dlaczego nie tak. Tyle w związku z Pani pytaniem o zadawanie pytań.

W pracy ze studentami, szczególnie na ćwiczeniach, chcąc ich zachęcić do literatury w ogóle, proponowałem im wiele utworów. Robiliśmy na tekstach oryginalnych wiele interpretacji. Pamiętam, że czterowersowym wierszem Dałczewa Lato zajmowaliśmy się przez półtorej godziny. To były szczegółowe analizy. Prezentowałem im także interpretacje innych badaczy: Romana Jakobsona interpretację wiersza Botewa Hadżi Dimityr, Nikoły Georgijewa, Radosweta Kołarowa. Wydałem zresztą kiedyś skrypt z interpretacjami bułgarskich badaczy literatury. Krąg autorów musiał, siłą rzeczy, być w pracy ze studentami dużo większy.

Pani pyta jednak także, jaki tekst zaproponowałbym polskiemu czytelnikowi. Zmodyfikuję nieco to pytanie, zastępując słowo „tekst” słowem „utwór". Przyjmuję, że chodzi w nim o utwór emblematyczny. Otóż dziś odpowiadam, że byłaby to powieść Iwana Wazowa Pod jarzmem. Staroć, ale bardzo emblematyczna. Gdyby zapytała mnie Pani o to samo dziesięć 
lat wcześniej, zanim zacząłem odkrywać tę powieść na nowo, zaproponowałbym w odpowiedzi dwa cykliczne zbiory opowiadań Jordana Jowkowa: Wieczory w Antimowskim zajeździe (1928) oraz Gdyby mogly mówić (1936). Też starocie. I też należałoby przetłumaczyć je na nowo. To proza, która nie tylko przedstawia, ale i mówi. Taką sobie cenię. Jeśli czytamy Józefa i jego braci Tomasza Manna, to ta powieść koresponduje z Biblią w sposób bezpośredni. Jeśli czytamy Jowkowa, to ten związek jest magiczny, tajemniczy i zagadkowy. Oczywiście utworów i autorów jest więcej, także spośród poetów, ale emblematycznie i w celu, o jaki Pani chodzi, dokonałbym takiego wyboru.

Zdarzyło się, że praca nad przekładem doprowadziła Pana do jakiegoś rodzaju ważnej wiedzy, redefinicji wcześniejszego sposobu rozumienia kultury bułgarskiej lub jej wątku albo odsłoniła jakieś regularności, wzór kulturowy?

Tak. Zdecydowanie tak. Najbardziej wymownym tego przykładem była praca nad nowym przekładem powieści Pod jarzmem Iwana Wazowa. Opisałem to szczegółowo w obszernym artykule Tłumaczac „Pod jarzmem" Iwana Wazowa. Choć może bardziej właściwe byłoby powiedzieć, że przekład był rezultatem i udokumentowaniem wcześniejszej reinterpretacji tego utworu, dostrzeżenia w nim różnorakich walorów, których postanowiłem dowieść przekładem. Ale takich utworów jest w moim dorobku więcej: powieść Antychryst Emiliana Stanewa przetłumaczyłem w konwencji legendy, nowelę Indże Jordana Jowkowa stylem ballady. Proza bułgarska wykazuje dużą skłonność do uwznioślania tematów, bohaterów poprzez taką oprawę gatunkowo-stylistyczną. Te utwory dają więcej możliwości przekładania z kultury do kultury. Bez mała cała proza Jordana Jowkowa jest „ukrytą” transpozycją wielu wątków biblijnych, łącznie z przestrzenią regionu Dobrudży jako ziemskiego, dobrego raju. Pokłady metaforyczności w prozie bułgarskiej, choć nie zawsze oczywiste, są bardzo rozległe. A sami Bułgarzy mówią o własnej literaturze, że jest nazbyt realistyczna.

Też podświadomie przez całe lata czytałam Jowkowa czy Pelina jako realistów i ciągle mi coś nie pasowało, jakby tam była jakaś nadwyżka. Z czego wynika, Pana zdaniem, ta metaforyzacja w bułgarskiej literaturze i na ile powinna być ona uwzględniona w procesie przekładu?

W procesie przekładu powinna ona być uwzględniona na ile tylko się da. Tłumacz nie może tu nic zmienić w sposób istotny. Może tylko tę metaforyzację ewentualnie bardziej uwydatnić, o ile owo uwydatnienie 
jest uzasadnione jego rodzimą kulturą, do której przekłada dany utwór. Bo tak przecież bywa, że pewien rys kulturowy może funkcjonować w jego własnej kulturze w sposób wyrazistszy, choć z punktu widzenia funkcjonalności jeden i drugi są sobie równoważne, ale inna jest ich intensywność w odbiorze.

Mówiąc o nie dość uwydatnionej literaturoznawczo i w krytyce literackiej metaforyzacji w literaturze bułgarskiej, mam zawsze na myśli konkretne utwory, które mogłyby, a wręcz powinny być wzbogacone interpretacyjnie. Dotyczy to głównie prozy, ale i poezji, w której metaforyczność jest jakby z natury rzeczy bardziej widoczna. Kiedy czytałem Księgi Jakubowe Olgi Tokarczuk, to ogromne wrażenie zrobiła na mnie pierwsza scena powieści, kiedy to ks. Benedykt Chmielowski wyrusza wczesnym rankiem ze swojej plebanii do rabina Eliszy Szora, do Rohatynia, pośród niezwykle gęstej i nieprzeniknionej mgły, w której świata nie widać. Stopniowo, wraz ze zbliżaniem się do miasteczka, mgła rozrzedza się, widać ludzi i wozy podążające na targ, pierwsze domy. I tak z tej mgły wyłania się świat przedstawiony powieści, który z każdą powieściową kartą rozlewa się w szeroką panoramę obfitującego w niezliczone postaci i miejsca, rozległego w czasie świata powieści. Toż to wspaniała metafora aktu powieściowej kreacji tego świata. Proza zawiera w sobie dużo poezji. I jak nie odczytywać metaforycznie ramy kompozycyjnej powieści Wazowa Pod jarzmem, która rozpoczyna się sceną życiowej sielanki, w równie sielankowej scenografii przyrody, a kończy pełną tragizmu sceną powieszenia przed rzeźnią? Ramą, która jest w dodatku zamkniętym cyklem czasu natury - od wiosny do wiosny.

Zadaniem tłumacza jest dostrzec to, by sielankowej intensywności $\mathrm{w}$ tej pierwszej scenie dać równoważny wyraz w intensywności tragizmu w scenie finałowej. Ale to nie jedyna wielka metafora w tej powieści. Jest nią także główny bohater Bojczo Ognianow, otrzymujący powieściową nominację $\mathrm{w}$ postaci tego imienia i nazwiska $\mathrm{z}$ ust duchownego, nieopodal cmentarza żydowskiego. Taką metaforą są armatki z pni czereśni jako oręż przeciwko potędze imperium osmańskiego. Analogicznie do użytych w czasie powstania styczniowego u nas, o czym powieść Wazowa informuje. I wiele innych. Proza sięga do poezji, kiedy chce przemówić bardziej emocjonalnie i głębiej.

Czy Pana zdaniem powieść Wazowa jest otwarta na nowe odczytania? Pozwala zrozumieć również dzisiejszą rzeczywistość?

Nie wiem, czy pomaga. Ludziom bardzo trudno przychodzi rozumienie rzeczywistości. Być może pomocne stają się dopiero bolesne 
doświadczenia w życiu społecznym, osobiste cierpienia, ale oby nie były one jedynym sposobem. Trudno mi w tych sprawach wyrokować. Sądzę natomiast, że ten utwór zawiera w sobie przesłanie skierowane także do dzisiejszego odbiorcy. Ma ono zresztą charakter uniwersalny, a z filozofią polskiej historii czasów nowożytnych związany bardzo ściśle. Nie jest to bowiem powieść historyczna, lecz powieść o miejscu i roli historii w życiu narodu. Przesłanie to głosi, że wolność człowieka i niepodległość narodu są dziejową koniecznością, ale walka o nie, niepoparta racjonalną strategią i właściwą oceną sytuacji, jest natchnionym szaleństwem, jak mówi wprost sam Wazow, i zaczyna się w scenerii i atmosferze wręcz karnawałowej, a kończy wyłącznie tragicznie. W kategoriach racjonalnych zasługiwałaby na potępienie, ale w sferze emocjonalnej zasługuje na poetyckie uwznioślenie. Jest bowiem próbą urzeczywistnienia zbiorowego marzenia o istnieniu $\mathrm{w}$ historii. Skojarzenia $\mathrm{z}$ polskimi powstaniami stają się nieuchronne, także w sferze ich ocen i interpretacji. Niezależnie od tego, jak bardzo doniosłe jest to przesłanie, to problem wolności ma w Pod jarzmem wymiar znacznie szerszy. Dotyczy również wyzwolenia się z ograniczeń narzuconych przez obyczajowość patriarchalną, a nawet zaskakująco aktualnie brzmiących postulatów praw kobiet, których rodowód sięga końca XIX wieku i jest, bo jakżeby inaczej, socjalistyczny. Wprawdzie Wazow wkłada je w usta studiującego w Moskwie Kandowa, ale zaświadcza, że taki wymiar wolności również wówczas zaistniał w świadomości społecznej. Aż dziw, że tak długo wciąż jest aktualny. Sądzę również, że sposób literackiego przedstawienia owego przesłania jest w tej powieści bardzo współczesny, bo urzeczywistnia się w ogromnym stopniu na poziomie metaforyzacji świata przedstawionego. Może powiem coś zaskakującego, sam zresztą w pewnym momencie, jeszcze przed przystąpieniem do przekładu, nie mogłem sobie uwierzyć, ale jest to powieść natchniona.

\section{Jak Pan doszedł do tego wniosku?}

Całościową, szczegółową jej analizą. Wyczuwam jednak, że spodobało się Pani samo określenie, więc parę słów o tym, skąd się wzięło. $\mathrm{W}$ powieści jest rozdział zatytułowany przez autora w dosłownym brzmieniu Pijaństwo narodowe lub Pijaństwo narodu. Oczywiście Wazow nie miał na myśli pijaństwa jako takiego, choć w powieści jest kilka natchnionych libacji, ale akurat $\mathrm{w}$ tym rozdziale takiej nie ma. Wazowowi chodziło o upojenie. Tyle że to słowo zrobiło karierę u nas w okresie Młodej Polski, a więc trochę później. Zresztą podobnie w modernizmie bułgarskim, gdzie spotykamy wyrażenie „от щшастието пиян” czy 
„опиянение” („upojony szczęściem, upojenie”). W rozdziale tym Wazow docieka, jak doszło do powstania kwietniowego, i w pewnym momencie powiada (zacytuję w najpierw oryginale): „[Ние] се чудим и маем какво е било това умствено опиянение, това сюблимно безумство на народа”. W przekładzie brzmi to tak: „dziwimy się i nie możemy uwierzyć, jak doszło w umysłach do tego oddania się upojeniu, do tego natchnionego szaleństwa”. Rozdziałowi nadałem tytuł Natchnione szaleństwo. Jest bardziej wymowny niż Upojenie narodowe, lepiej oddaje intencję Wazowa.

Słowem „natchniona” opatrzyłem też samą powieść. O wielu tego powodach już rozmawialiśmy, napisałem o nich także w artykule. Tu dodam, że powstała szybko, nie miała żadnych rodzimych wzorców, a stopień jej zorganizowania, zwłaszcza w planie metaforycznym, jest wysoki i rozległy. Chcę tu dopowiedzieć, w związku z metaforyzacją, że owo natchnione szaleństwo objawia się już w pierwszej niezwykle idyllicznej scenie, którą zakłóca Iwan Królew, późniejszy główny bohater Bojczo Ognianow, przeskakując parkan domu Marka Iwanowa. Robi się raban, zjawia się żandarmeria turecka. Tak rewolucja narodowa wdziera się w „życie Bułgarów w przededniu wyzwolenia”. Marko mówi mu przy najbliższej okazji, że zawsze będzie mile widzianym gościem, ale niech wchodzi drzwiami. W centrum akcji jest Biała Cerkiew, czyli miejsce „sakralne" z punktu widzenia tożsamościowego. Tyle toponimów w powieści Wazow daje w brzmieniu tureckim, a akurat ten przemianowuje z Akçe kilise, jak nazywał się jego rodzinny Sopot. Inny przykład. Przedstawienie Genowefa cierpiaca bez miary, wystawiane już wielokrotnie w Białej Cerkwi, wzrusza niezmiennie mieszkańców, którzy utożsamiają się z cierpieniami, jakie los zgotował bohaterce sztuki, bo jest pewna analogia z cierpieniami, jakie zadają im Turcy. Tym razem przygotowane przez Ognianowa przedstawienie kończy się nieoczekiwanie i spontanicznie pieśnią patriotyczną. Posiady w Ałtynowie kończą się pieśnią buntowniczą. Opatrzność Boża jest ucieleśniona w ślepcu, wszyscy bohaterscy rewolucjoniści, którzy giną, są spoza Białej Cerkwi. Największą bezkompromisowość i odwagę spośród mieszkańców Białej Cerkwi przejawia wiejski przygłup Munczo, którego imię — pośród tylu imion mówiących w powieści - nic nie mówi, bo jest formą zdrobniałą od imion będących hipokoristikonami, w dodatku rzadko występującymi. Jak tu nie myśleć o powieści natchnionej? 
Powiedział Pan wcześniej o Liliewie, że doprowadził do kulminacji modernistyczną samoświadomość literacką. Czy to natężenie literackości było odrębnym wyzwaniem w procesie przekładu jego poezji?

No właśnie. Co ma począć tłumacz, którego z jednej strony motywuje chęć popularyzowania poety ważnego w kanonie literackim danej literatury, ważnego z różnych powodów literackich, ale i z uwagi na przywiązanie emocjonalne odbiorców oraz miejsce, jakie zajmuje on w świadomości społecznej; a z drugiej strony jest zafascynowany jego wierszotwórczą doskonałością, tonacjami emocjonalnymi? Albo zrezygnować, albo podjąć wyzwanie. Jak powiada mój najmłodszy wnuk — „Dziadku, bez ryzyka nie ma zabawy”. Podjąłem je z pokorą i myślą, że jeśli uda mi się całą orkiestracją osiągnąć dźwięczny ton, nie tracąc nic z symbolistycznych pejzaży duszy, i jeśli jeszcze oddech przy czytaniu tych przekładów będzie bliski rytmowi oddechu Liliewa, to będzie w tym pożądana doza prawdziwości literackiej. Chciałoby się powiedzieć za Liliewem — „nie trzeba więcej”. Przypomina mi się przy tych słowach fragment jednego z wierszy:

Tracja w pól dźwięcznej podzięce,

bezbrzeżnych, złotokłosych,

dusza beztroska się unosi.

Nie trzeba więcej.

Nie trzeba więcej nad fal muśnięcie

$[\ldots]$

Pisał Pan pracę doktorską o Liliewie i Dałczewie, których twórczość obrazuje też pewien moment w trwaniu literatury: przejścia od złożoności do prostoty, od gęstej esencji do jasnej klarowności. Mam wrażenie, że to są bardzo interesujące momenty w historii literatury, w których wytwarza się coś nowego. W jakim stopniu badanie twórczości obu tych poetów wpłynęło na Pana myślenie o literaturze bułgarskiej? Czy momenty przesilenia $\mathrm{w}$ bułgarskiej kulturze biorą się $\mathrm{z}$ negacji i zerwania czy też z kontynuacji i dialogu z tradycją, czyli mówiąc metaforycznie: jak Dałczew ma się do Liliewa?

Poezję Atanasa Dałczewa cenię sobie w stopniu nie mniejszym, choć kształtowała się ona kontrapunktowo do poezji Liliewa. Taki już los literaturoznawcy! Czytelnikowi, nawet krytykowi literackiemu, wolno mieć preferencje - filozoficzne, emocjonalne i wszelkie inne. Literaturoznawca jest zobowiązany do działań i ocen obiektywizujących, sytuujących w procesie historycznoliterackim wobec czegoś i na rzecz czegoś. Jak 
najmniej epitetów oceniających, jak najwięcej nazywających i opisujących. Jako tłumacz mogę sobie pozwolić na oceny emocjonalne.

Wracając do Dałczewa. Chętnie byłbym go przetłumaczył, gdyby nie fakt, że wcześniej zrobiła to znająca język bułgarski Anna Kamieńska. Zresztą zaprosiła mnie do swego tomiku, w którym są moje przekłady fragmentów, publikowane wcześniej w „Twórczości”. Dałczew, jak Pani już powiedziała, jest pod wieloma względami polemiczny wobec Liliewa. Jest to przejście do innego języka poetyckiego, do innych form, innego brzmienia i tonacji emocjonalnej, ale nie jest to przejście do klarowności i prostoty. Jeśli one są, to tylko pozornie. Wpadł mi kiedyś w ręce tomik wierszy Rafała Wojaczka po angielsku, dwujęzyczny. W jednym z wierszy czytam takie oto wyznanie, że chciałby napisać jeszcze dużo wierszy, chciałby pisać długopisem. Prostota wypowiedzi oczywista. Spoglądam na przekład angielski i w tym miejscu jest „ballpen”, czyli „pióro kulkowe”. Całą głębię prostoty diabli wzięli. Taka też jest prostota Dałczewa. Weźmy dla przykładu czterowiersz Lato, krótki i w tej formie jakby liliewowski, a w swej prostocie jakby odpoetyczniony, czyli antyliliewowski:

Na drzewach liście uparcie milczały

i cienie się rozlały jak kałuże.

Na wschodzie dwa obłoki w bezruchu

trwały, jakby rzuciły kotwicę na dłużej.
Листата на дърветата мълчеха и сенките лежеха като локви.

Два облака стоеха неподвижно

на изток, сякаш спуснали там котва.

Są w tym czterowierszu zaledwie dwa porównania: „cienie [...] jak kałuże” oraz „obłoki w bezruchu [...] jakby rzuciły kotwicę na dłużej”. W dodatku cienie przypominają kałuże, a więc odpoetycznienie jest tu oczywistą oczywistością. I tylko jedno słowo wiąże się z motywem tytułowego lata — „liście”. Dominuje statyczność, milczenie, bezruch, swoista martwota. Zwróćmy jednak uwagę, jak bardzo uwidoczniony został motyw wody i ochłody, których w tym wierszu tematycznie nie ma wprost: cienie, rozlały się (dodane przeze mnie, ale nie narusza statyczności, bo wskazuje na stan czasu przeszłego), kałuże, obłoki, kotwica. Najwięcej zatem jest tego, czego faktycznie w tym letnim skwarze nie ma, co przywoływane jest głównie poprzez porównania, a co jest życiodajne, czego się pragnie. W tym wszechobecnym pragnieniu kryje się potężna metafora mająca także wydźwięk metafizyczny. Metafizyczna pełnia jest źródłem życiodajnego pragnienia. To jakby sedno głębi, jaką ma prostota w poezji Dałczewa. Liliew by mówił o pragnieniu (marzeniu), ubrał je w dźwięki, barwy, wyśpiewał; Dałczew je wyraża ukryte w poetyckim obrazie. O tym wierszu można by mówić jeszcze długo. 
Pracując nad przekładami literackimi, wiele uwagi poświęca Pan strukturom gramatycznym języka bułgarskiego, które w sposób nieuchronny rzutują na ogólną strategię przekładową na język polski.

Dotyczą one różnych konkretnych zagadnień, ale wspomnę tylko o problemie określoności i podmiotu zdaniowego. Jak wiadomo, jedną z cech konstytutywnych tego języka jest rodzajnik, określony i nieokreślony. Przyjęło się z dawien dawna wśród gramatyków, że rodzajnika nie tłumaczymy. Nie tłumaczymy, ale w literaturze zasada ta nie obowiązuje w sposób bezwzględny. Kontekst logiczny i potrzeba nadania pewnej ekspresji wręcz wymusza w języku polskim dodanie określoności. Oto przykład: „Бе пълно с конски каруци. Те идваха от покрития със слама мост [...] и почваха по улица Гурко [...] към центъра. Конете вяло следваха пътя: една затисната от капаците на очите безкрайна улица”. Początek ostatniego zdania powinien w przekładzie brzmieć: „Konie ospale podążały tą trasą: [...]”.

Jakby mało było samego rodzajnika, to słowom nim opatrzonym dodaje się jeszcze obowiązkowo mnóstwo zaimków dzierżawczych. Oczywiście nie wszystkie możliwe jednocześnie. Czyli mamy takie zdanie: „Той се появи с новата си шапка” - dosłownie: „On pojawił się w swoim nowym kapeluszu (tym właśnie)”. Zupełnie jakby chodziło o rozwianie ewentualnych wątpliwości, czy kapelusz należał do niego. Oczywiście ten nadmiar określoności ma uzasadnienie. Choćby takie, że kapelusz pozbawiony rodzajnika i zaimka dzierżawczego w wyrażeniu „Той сваля шапка пред него” oznacza, że chodzi o oddanie szacunku lub wyrażenie podziwu dla kogoś poprzez uniżone zdjęcie przed nim nakrycia głowy. Gdyby jednak tłumaczyć dosłownie, to mielibyśmy w tekście urodzaj zaimków dzierżawczych, co raziłoby w języku polskim, bo takiej potrzeby on nie ma. Gdyby w zdaniu o kapeluszu usunąć podmiot (Той/On), to byłoby ono dalece niepoprawne gramatycznie. Nieunikniona obecność formalnego podmiotu jest także, jak mi się zdaje, pewną formą określoności. Takich problemów w języku polskim nie ma, a tłumaczymy na ten język.

Rozwinę nieco ten temat. Przetłumaczyłem powieść Jordana Jowkowa Чифликът край границ̧ата (Majątek przy granicy), do której mam sentyment, bo to bodaj pierwszy w literaturze bułgarskiej typowy romans. Główna bohaterka o imieniu Nona ciągle promienieje uśmiechem, ma narzeczonego, który jest ze Szwajcarii (tam pobierała nauki) i ma ją niebawem odwiedzić w majątku, aby się oświadczyć. Przedłużające się oczekiwanie sprawia, że zakochuje się w podporuczniku Gałczewie z pobliskiej strażnicy. Wątek romansowy nie jest jedynym, ale nie w tym 
rzecz, a w tym, że podporucznik występuje wyłącznie z nazwiska (chyba tylko trzy razy z imienia, a w wypadku Nony jest odwrotnie). Dość sobie wyobrazić, jaka byłaby w przekładzie polskim statystyka użycia jej imienia i jego nazwiska w stosunkowo niewielkiej powieści, gdyby ci bohaterowie nie pojawiali się w zdaniach jako podmioty domyślne. A w powieści są też inni bohaterowie. Wydam ten przekład w jakiejś dalszej kolejności, ale zrobiłem go także gwoli zmagania się z określonością w języku bułgarskim.

A czy czasy i ich wielość, zwłaszcza czasów przeszłych, w języku bułgarskim również stały się dla Pana rodzajem takiego wyzwania?

Jak najbardziej. To oczywiste, że całą gramatykę tłumacz powinien brać pod uwagę. We fragmencie, do którego Pani nawiązuje, odnosiłem się do określoności w zakresie przedmiotu wypowiedzi, ale jest też określoność podmiotu wypowiedzi względem treści wypowiedzi, gramatycznie uzewnętrzniona tzw. trybem nie-świadka, kiedy podmiot wypowiedzi sygnalizuje, że mówi o zdarzeniu, którego nie był bezpośrednim świadkiem i nie może go uwiarygodnić swoją relacją. Jest też określoność czasowa, istotna zwłaszcza w odniesieniu do czasu przeszłego nieokreślonego, dotyczącego zdarzenia, które miało miejsce w ogóle, a moment samego zdarzenia, jak i jego dokonaność lub niedokonaność nie są istotne. Również czas zaprzeszły jest pewną formą określoności. Wprawdzie ten czas jest gramatycznie w języku polskim, ale stał się funkcjonalnie bardziej kategorią stylu niż żywej gramatyki. Generalnie możemy za gramatykami powiedzieć, że w tłumaczeniu tych subtelności możemy nie uwzględniać. Możemy, ale w przekładzie literackim tak nie jest i decydują o tym konteksty. Bywa na przykład, że pytanie „Ти чел ли си тази книга?", sformułowane z użyciem czasu przeszłego nieokreślonego, powinniśmy przetłumaczyć „Czy ty w ogóle czytałeś tę książkę?”. Bywa, że obecność trybu nie-świadka powinniśmy zaznaczyć modulantem (partykułą - według innych autorów gramatyki) „podobno” lub jego synonimami typu ,jak mówią”, „chodziły słuchy” itp. O tym wszystkim decydują konteksty. I tłumacz powinien być na nie wyczulony. Może nie zwałbym tego wyczulenia wyzwaniem, ale te subtelności są ważne. W literaturze każde słowo, wszystko jest ważne.

Ze struktury gramatycznej języka bułgarskiego, już poza sferą określoności i nieokreśloności, wynika dla tłumacza, zwłaszcza tłumacza poezji, jeszcze jedno wyzwanie, o którym warto tu powiedzieć, ale jest ich jeszcze kilka. Aby wyrazić zależności między podmiotem i dopełnieniem, wymagającymi często rodzajników postpozytywnych, które czy to w for- 
mie krótkiej, czy pełnej są jednosylabowe, niezbędne jest użycie przyimka, który też jest jednosylabowy. W poezji klasycznej, w której rytm, metrum i rym odgrywają istotną rolę, ta arytmetyka ma swoje konsekwencje dla wszystkich powyższych kategorii wersyfikacyjnych, ale też dla kształtu metafory. Bardzo trudno jest w niej zderzyć znaczeniowo dwa elementy przedmiotowe. Dla przykładu, Liliew nie dałby swemu tomikowi tytułu Петна на луната, w którym byłyby dwie sylaby „zbędne” (на oraz -та). Dał tytuł Лунни петна (Odblaski księżyca), czyli użył epitetu metaforycznego. Ja odwróciłem w przekładzie strukturę gramatyczną tej metafory, ponieważ, moim zdaniem, jest ona bardziej nowoczesna, bliższa poezji współczesnej, jeśli jej granicą początkową miałaby być poezja awangardowa, ale przecież ten typ metafory występuje już w polskim romantyzmie, choćby u Słowackiego. W każdym razie epitet metaforyczny jest bliższy poezji bułgarskiej aż do czasu, kiedy odchodzi ona od klasycznych wzorców wersyfikacyjnych. Ale nawet wówczas nie bardzo mogę sobie wyobrazić, jak można by bezboleśnie przetłumaczyć na język bułgarski ten fragment wiersza Notre Dame III Juliana Przybosia: „Rozgiąłem łuk przestrzeni w sklepieniu stuleci”. To poniekąd graniczy z cudem. Skłonny jestem w związku z tym myśleć, że epitet metaforyczny jest w ogóle bliższy poezji bułgarskiej ze względu na taką, a nie inną strukturę języka. Tłumacz powinien to brać pod uwagę i próbować, ale bez nadmiernej przesady i w oparciu o racjonalne uzasadnienie, którym w moim wypadku był polski romantyzm literacki, wpasować tłumaczonego poetę w tradycję własnej literatury.

Lada chwila ukaże się w Polsce obszerny wybór wierszy Nikołaja Kynczewa. To poeta, z którym łączyła Pana wieloletnia przyjaźń i którego twórczość niejednokrotnie tłumaczył Pan już wcześniej. Można potraktować ten zbiór jako swego rodzaju syntezę literackiej obecności Nikołaja Kynczewa w Polsce?

Nikołaja Kynczewa tłumaczyłem chyba od 1967 roku. Równolegle z poetą i tłumaczem Janem Zychem, który umieścił jego utwory w antologii Z poezji bułgarskiej (1972). Pierwszy tomik jego wierszy Niczym ziarno gorczycy wydałem w 1981 roku po ponad dwuletnich staraniach ze strony Wydawnictwa Literackiego, by uzyskać zgodę Bułgarskiego Związku Pisarzy, ponieważ poeta ten był objęty cenzurą... estetyczną. Ten tomik otworzył drogę do wydań jego poezji w innych krajach. Dużą zasługę ma w tym Andrzej Kurz, ówczesny dyrektor wydawnictwa. Powstał precedens. Potem wydałem w Bułgarii dwujęzyczny tom Posłanie od piechura. Tom Przeciwko nieobecności, o który Pani pyta, jest zbiorem wszystkich 
moich publikowanych wcześniej przekładów, także tych wierszy, których Nikołaj Kynczew nie umieścił w najpełniejszym, dwutomowym wydaniu z 2005 roku. Ale doszły też przekłady wierszy z ostatnich lat jego życia. Jak chyba już wspominałem, wiele jego wierszy jest nieprzetłumaczalnych, ale mogą kogoś skusić, nie włączyłem też przekładów Jana Zycha, więc nie jest to synteza obecności tego poety w Polsce, a tylko moje przekłady zebrane. Okazało się, że jest ich sporo.

\section{Poezję Kynczewa określa Pan jako frazeologiczną.}

Na użytek domowy, dla żartu, mówię często: „Jak tylko wstanę rano, to cały dzień jestem na nogach...". Stosuję w tym wypadku zabieg typowy dla niemal całej poezji Nikołaja Kynczewa, poza wczesnym okresem twórczości. Frazeologizm „być cały dzień na nogach” oznacza, że jest się bardzo zapracowanym, zajmując się różnymi obowiązkami bez chwili wytchnienia. Powiedzenie $\mathrm{z}$ jego użyciem jest tyleż prawdziwe, co nieprawdziwe. Prawdziwe jest $\mathrm{w}$ nim stwierdzenie, że po wstaniu rano z łóżka jest się na nogach, ale to wcale nie musi oznaczać, i tak jest w moim przypadku, że krzątam się niezmordowanie od rana do wieczora. Jest to więc kontekstowo i sytuacyjnie warunkowana gra z prawdą w samym języku, służąca $\mathrm{w}$ istocie żartobliwemu usprawiedliwieniu braku aktywności fizycznej. Jeśliby kontynuować ten żart, to mógłbym dodać: „... a czasami nawet wychodzę z siebie” i to stwierdzenie byłoby prawdziwe jedynie w sensie przenośnym, bo przecież nie w sensie rzeczywistym. A jeśliby dodać jeszcze: „...wychodzę z siebie i staję obok”, to groteskowość, przepraszam za wyrażenie, „mojej sytuacji lirycznej” sprowadzałaby się już do całkowitego braku adekwatności między rzeczywistością językową, tworzoną przeze mnie poprzez ciąg wyrażeń frazeologicznych, i moim stanem faktycznym. Co ważne, ja wykorzystałem w tym wypadku gotowe związki słowne, a więc takie, które dotyczą nie mojej sytuacji jednostkowej w danych okolicznościach, lecz mogą być wykorzystane przez wszystkich użytkowników języka.

Dużo było o mnie, więc najwyższy czas przejść do Kynczewa. Weźmy choćby fragment wiersza Ach!:

Życie to taka najwyższa rzecz,

że jeśli spojrzysz na nie jak należy,

spada ci czapka zamiast głowy.

Mamy w nim trzy wyrażenia typu frazeologicznego: „najwyższa rzecz” (sprawa, idea), „spojrzeć jak należy” oraz „głowa ci spadnie” (może spaść). Okazuje się, że w języku zawiera się gotowa metaforyka i poeta 
może ją efektownie i efektywnie wykorzystywać do tworzenia swojego obrazu poetyckiego. Albo inny przykład z wiersza Kino (kursywą wyrażenia frazeologiczne):

I choć słońce, zwiesiwszy głowę, folguje sobie,

i obfitość powietrza aż w nim pychę rodzi,

zajdźmy gdzieś... bo niemota, jak wiadomo,

przez czas krótki była sercu kina miła.

W ciemnościach wszystko jasno ci wyłożę!

W wierszach z ostatnich lat życia Kynczewa częstotliwość i zagęszczenie frazeologizmów są tak duże, że chyba nie da się ich przetłumaczyć na żaden język. I zapewne w każdym z języków braknie jednego lub kilku frazeologizmów. Czasami myślę sobie, i takie mam dogłębne wrażenie, że język w tej poezji mówi sam. Dużo w niej frazeologizmów, zagadek słownych, gry językowej, kalamburów, sentencji, paradoksu, a więc tego wszystkiego, co organicznie jest w języku, i poeta tylko uruchamia ten językowy arsenał do wyrażenia siebie i świata. To wcale nie jest łatwe.

Od pewnej polskiej badaczki, którą cenię, usłyszałam, że bycie bułgarystką pozwoliło jej na nowo spojrzeć na wiele spraw dotyczących również własnej kultury. Czy bywa lub bywało tak również w Pana przypadku?

To dobra wiadomość. Na ogół jest tak, że uczestniczymy w innych kulturach, czytając w oryginale lub w przekładach książki autorów obcych. Stają się oni lub nie stają autorami naszymi, w zależności od tego, czy nam się podobają, czy nie. Rzadziej bywa, że poznajemy inną literaturę w sposób bardziej całościowy, w jej możliwie najszerszym otoczeniu kulturowym i językowym, obserwując również z bliska sposób komunikowania się, nie tylko na poziomie samego języka, lecz także na poziomie gestów, czyli na poziomie stylu komunikowania się. Moje doświadczenia w tym zakresie nauczyły mnie, że nie należy innej kultury traktować z poczuciem wyższości, a z najwyższą pokorą. To, że się różnimy, nie świadczy, że jesteśmy lepsi lub gorsi. Kultury mówią często różnymi językami, ale równie często mówią to samo. Intensywność problematyki może nie być taka sama, ale to zależy od zapotrzebowania społecznego i jego skali, i wielu innych uwarunkowań, także w strukturze języka. To temat na elaborat. 
O jakie potencjalne nieporozumienia kulturowe, Pana zdaniem, szczególnie łatwo w tym konkretnym przypadku polsko-bułgarskim?

Nie nazywałbym tego nieporozumieniem kulturowym ani też niezrozumieniem. W pierwszej kolejności jest to efekt braku dostatecznego zainteresowania. I to nie jest przypadek tylko polsko-bułgarski. Polska kultura oswajała bardzo długo kulturę z kręgu łacińskiego, potem francuską, niemiecką, rosyjską, włoską, angielską, hiszpańską, skandynawską. Także kultury Dalekiego Wschodu. Stała za tym znacząca część polskiej inteligencji, programy szkolne, uniwersyteckie, prasa, wydawnictwa, ale przede wszystkim wybitni twórcy, mający duży autorytet społeczny. Poezję obcą tłumaczyli wybitni poeci polscy. A proszę popatrzeć, jak to wygląda do dziś w relacjach polsko-bułgarskich. I nie tylko. W okresie międzywojennym autorytet prof. Bojana Penewa, historyka literatury i krytyka, sprawił, że literatura i kultura polska zostały tak mocno spopularyzowane i wręcz zmitologizowane, że owoce tego zjawiska zbieramy do dziś. A u nas? Problem sprowadza się zatem do stopnia oswojenia innej kultury. I oczywiście tu nie ma niczyjej winy. Po prostu tak jest, a bywa jeszcze gorzej. Gwoli zilustrowania: kiedyś przez chwilę zastanawiałem się, dlaczego tak łatwo przychodzi nam przyswoić sobie formy grzecznościowe w innych kulturach - don, sir, monsieur, a kiedy tłumacz literatury bułgarskiej sięga po utwór Aleko Konstantinowa Baj Ganio, to nie może tego „baj” zostawić bez objaśnienia, choć bardzo oczytany czytelnik mógłby przecież skojarzyć je funkcjonalnie z tytułem Pan Balcer w Brazylii Konopnickiej, a o to przecież chodzi. Poniekąd programowo nazwałem kiedyś oswajanie innej kultury oswajaniem skorpionów. Ten proces wymaga czasu, pracy, cierpliwości, otwartości i twórców.

Ostatnie książki sfinansował Pan sam, nakład Pod jarzmem - Pańska córka. Nie chcę tu pytać o reguły rynku wydawniczego czy stopień jego otwartości na literaturę bułgarską, ale raczej o tę potrzebę, która sprawia, że staje się Pan nie tylko twórcą, lecz także mecenasem kultury?

Nie traktuję tego jako mecenatu. Jest to dla mnie najkrótsza i najmniej uciążliwa droga do celu. A tym celem jest popularyzowanie akurat głównie klasyki, co z góry skazane jest na działania poza rynkiem wydawniczym. I nie mam o to żalu do mechanizmu rynkowego. Spłacam w ten sposób swój dług wdzięczności wobec Bułgarii i jej kultury, jakkolwiek patetycznie by to brzmiało. Wiele tej kulturze zawdzięczam w życiu. Ale robię to także i przede wszystkim $z$ wewnętrznej potrzeby bliskiego obcowania $\mathrm{z}$ literaturą w formacie szerszym niż tylko czytelniczy. 
Mógłby Pan opowiedzieć o ulubionych autorach, którzy towarzyszą Panu od lat? Nie pytam tutaj tylko o te literatury, którymi zajmuje się Pan zawodowo.

Autorów ulubionych i książek mam wielu i wiele. Ich lista w różnych okresach się zmieniała, jak u każdego, ale nadal jest ich dużo, choć rzadko już przybywa nowych, bo dostęp wzrokowy do nich jest w moim przypadku coraz trudniejszy. Z autorów polskich ogromne wrażenie zrobiła na mnie Olga Tokarczuk i jej Księgi Jakubowe. Ale rozumiem, że mam pominąć autorów polskich i bułgarskich. Jakieś dziesięć lat temu przeczytałem raz jeszcze całego Tomasza Manna, całego Gogola, Josepha Conrada, z dużym entuzjazmem przeczytałem Portret damy Henry'ego Jamesa, sonety Szekspira w przekładzie Stanisława Barańczaka, wróciłem do lektury Eliota, odświeżyłem sobie książki Kundery, Hrabala, przeczytałem nowy przekład Przygód dobrego wojaka Szwejka autorstwa Antoniego Kroha z brawurowym wstępem mojego profesora i przyjaciela Jacka Balucha... W zasadzie unikam postmodernistów i żywię przekonanie, że realizm jest wciąż żywą metodą pisarską...

\section{Czy ma Pan ulubione miejsce w Bułgarii?}

Mam ich wiele. Uzbierało się przez lata. Spośród dużych miast lubię Sofię, Wielkie Tyrnowo, Płowdiw, Warnę. Nad morzem wciąż jeszcze najbardziej lubię Sozopol, w górach Małko Tyrnowo w Strandży, widokowo wieś Czała w Rodopach, пошъей Борино, a najchętniej jadałbym w gospodzie Ostatni Grosz (Последен грош), о ile jeszcze istnieje, we wsi Mała Cyrkwa niedaleko Samokowa.

\section{Dziękuję za rozmowę.}

Wojciech Gałązka, Sylwia Siedlecka

\section{O literaturze bułgarskiej, języku i przekładzie Rozmowa z Wojciechem Gałązką}

STRESZCZENIE | Rozmowa z Wojciechem Gałązką, bułgarystą, literaturoznawcą i tłumaczem literatury bułgarskiej, dotyczy jego najnowszych przekładów artystycznych. W ciągu kilkunastu miesięcy, między 2019 a 2020 rokiem, w przekładzie Gałązki ukazało się sześć dzieł bułgarskich pisarzy i poetów: powieść Pod jarzmem Iwana Wazowa (2020); tomy poetyckie: Skądkolwiek wyjawiony Petyra Pyrwanowa (2019), Sezony uczuć Petyra Karaangowa (2020), Odblaski księżyca Nikołaja Liliewa (2020), Sen o szczęściu Pencza Sławejkowa (2020) oraz proza poetycka i wiersze zawarte w tomie Przeciwko nieobecności Nikołaja Kynczewa (2020). W wywiadzie omówione zostały kwestie związane z praktyką 
przekładową: struktury brzmieniowe, gramatyczne, przekładalność związków frazeologicznych, uwzględnienie konwencji literackiej w procesie przekładu, jak również zagadnienia problematyzujące przekład jako transfer między kulturami.

SŁOWA KLUCZOWE | Wojciech Gałązka, literatura bułgarska, język bułgarski, literatura polska, przekład, transfer kulturowy

\section{Войчех Галонзка, Силвия Сидлечка}

\section{За българската литература, езика и превода Интервю с Войчех Галонска}

РЕЗЮМЕ | Разговорът се фокусира върху най-новите художествени преводи на полския българист, литературовед и преводач на българска литература Войчех Галонзка. През периода 2019-2020 година в Полша са издадени шест превода на В. Галонзка: нов превод на романа Под игото на Иван Вазов (2020) и стихосбирките: Откъдето и да идва на Петър Първанов (2019), Сезоните на чувствата на Петър Караангов (2020), Лунни петна на Николай Лилиев (2020), Сън за щастие на Пенчо Славейков (2020), Против отсъствието на Николай Кънчев. В интервюто се разискват проблеми на преводаческата практика, напр. предаването на звуковите и граматичните структури, преводимостта на фразеологизмите, съобразяването с литературната конвенция в преводния процес, както и въпроси, свързани с разбирането на превода като междукултурен трансфер.

КлючОви думи ～| Войчех Галонзка, българска литература, полска литература, български език, превод, междукултурен трансфер

SYLWIA SIEDLECKA | dr nauk humanistycznych w zakresie kulturoznawstwa, adiunkt w Instytucie Slawistyki Zachodniej i Południowej Uniwersytetu Warszawskiego. Jej zainteresowania naukowe koncentrują się wokół antropologii widowisk w Europie Środkowo-Wschodniej oraz zagadnień wyobraźni społecznej. Prowadzi badania naukowe we współpracy m.in. z Instytutem Slawistyki PAN, Instytutem Teatralnym oraz Domem Spotkań z Historią w Warszawie. Tłumaczyła poezję słowacką. Autorka monografii, artykułów naukowych, esejów, reportaży, powieści i opowiadań. Ostatnio opublikowała zbiór esejów o Bułgarii pt. Złote piachy (2019). 